\title{
PENGARUH MODERNISASI SISTEM ADMINISTRASI PERPAJAKAN TERHADAP KEPATUHAN WAJIB PAJAK ORANG PRIBADI USAHAWAN DI ITC CEMPAKA MAS JAKARTA
}

\author{
Andry \\ Institut Bisnis dan Informatika Kwik Kian Gie \\ andrynainggolan@ rocketmail.com \\ Amelia Sandra \\ Institut Bisnis dan Informatika Kwik Kian Gie \\ amelia.sandra@kwikkiangie.ac.id
}

\begin{abstract}
Tax is one of the largest nation's country. To achieve the target of state revenue from the taxation sector, the Directorate General of Taxation takes steps in the framework of sustainable tax reform including tax reform reform in the field of policy and reform in the field of tax administration. So the tax reform creates a healthy and competitive tax system in encouraging Taxpayers to fulfill the rights and obligations of taxation. This study discusses the influence of modernization of tax administration system on taxpayer compliance of entrepreneurs in itc cempaka mas jakarta. Sampling technique used is non probability sampling with purposive sampling method and obtained data of 100 respondents from taxpayers compliance of entrepreneur in itc cempaka mas jakarta. Data analysis techniques and hypothesis testing to check each variable is done by descriptive statistical test, pooling test, classical assumption test, multiple regression analysis test, F test and t test using program SPSS 23. Based on the tests that have been done, it can be concluded that the modernization of tax administration system has an influence on the compliance of individual taxpayers.
\end{abstract}

Keywords: modernization, tax administration system, taxpayer compliance

\section{PENDAHULUAN}

Pajak merupakan sumber penerimaan negara yang sangat penting dan potensial.

Untuk mencapai target penerimaan negara dari sektor perpajakan dibutuhkan upayaupaya yang nyata, serta mengimplementasikan dalam bentuk kebijakan pemerintah. Direktorat Jendral Pajak mengambil langkah-langkah dalam rangka reformasi perpajakan yang berkelanjutan meliputi beberapa bidang, antara lain dalam modernisasi pelayanan dan administrasi, pengawasan wajib pajak, pengawasan internal, sumber daya manusia, modernsisasi sistem informasi dan teknologi lainnya (Direktorat Jendral Pajak, Laporan tahunan 2007).

Reformasi Perpajakan dilakukan bertahap. Tahap pertama dilakukan antara tahun 2002-2009. Pada periode tersebut, Direktorat Jenderal Pajak (DJP) melakukan dua buah perubahan mendasar. Pertama adalah Reformasi Administrasi yang meliputi restrukturisasi organisasi, perbaikan proses bisnis, dan penyempurnaan sistem manajemen sumber daya manusia. Sedangkan yang kedua dilakukan Reformasi Kebijakan, yaitu 
dengan amandemen atas beberapa undangundang perpajakan dan juga pemberian stimulus fiskal.

Tahap kedua reformasi perpajakan dilakukan antara tahun 2009-2012. Pada tahap ini perubahan DJP difokuskan kepada pengembangan sumber daya manusia dan penggunaan teknologi informasi dalam administrasi perpajakan.Pengelolaan terhadap sumber daya manusia merupakan sebuah perubahan subtansial dan belum pernah dijalankan pada perubahan sebelumnya (Madewing, Irmayanti 2013:16).

Besarnya perubahan yang dilakukan dalam reformasi perpajakan tampak sebagai upaya untuk mewujudkan DJP baru. DJP yang menjalankan administrasi perpajakan secara modern, berorientasi pada pelayanan kepada wajib pajak, dan memiliki nilai-nilai organisasi baru yang kuat. Konsep modernisasi administrasi perpajakan pada prinsipnya adalah merupakan perubahan pada sistem administrasi perpajakan yang dapat mengubah pola pikir dan perilaku aparat serta tata nilai organisasi sehingga dapat menjadikan Direktorat Jenderal Pajak (DJP) menjadi suatu institusi yang profesional dengan citra yang baik di masyarakat (Pandiangan,2008:6)

Oleh karena itu, sejalan dengan tujuan modernisasi yaitu untuk meningkatkan kepatuhan sukarela Wajib Pajak, meningkatkan kepercayaan masyarakat, dan meningkatkan produktivitas dan integritas aparat pajak. Maka program reformasi adminsitrasi perpajakan perlu dirancang dan dilaksanakan secara menyeluruh dan komprehensif. Perubahan - perubahan yang dilakukan meliputi bidang-bidang berikut: Struktur organisasi, Proses bisnis dan teknologi informasi komunikasi, dan Penyempurnaan manajemen sumber daya manusia. (Direktorat Jendral Pajak, Laporan tahunan 2007: 14)

Berdasarkan latar belakang masalah diatas, maka permasalahan dalam penelitian ini adalah pengaruh modernisasi sistem administrasi perpajakan terhadap kepatuhan Wajib Pajak Orang Pribadi Usahawan di ITC Cempaka Mas Jakarta.

\section{TELAAH LITERATUR}

Definisi pajak menurut UU nomor 16 tahun 2009 tentang Ketentuan Umum dan Tata Cara Perpajakan menjelaskan bahwa Pajak adalah kontribusi wajib kepada negara yang terutang oleh orang pribadi atau badan yang bersifat memaksa berdasarkan undang-undang, dengan tidak mendapatkan imbalan secara langsung dan digunakan untuk keperluan negara bagi sebesar-besarnya kemakmuran rakyat Terdapat beberapa teori yang menjelaskan 
atau memberikan justifikasi hak kepada negara untuk memungut pajak. Teori-teori tersebut antara lain adalah Teori asuransi, Teori kepentingan, Teori gaya pikul, Teori kewajiban mutlak, Teori gaya beli, Teori ini menyatakan bahwa negara bertugas untuk melindungi orang dan segala kepentingannya, meliputi keselamatan dan keamanan jiwa dan harta bendanya, yang menjadi alasan negara berhak memunggut pajak

\section{Modernisasi Sistem Administrasi Perpajakan}

Pengertian dari modernisasi sistem administrasi perpajakan adalah program pengembangan sistem dalam perpajakan terutama pada bidang administrasi yang dilakukan instansi yang bersangkutan guna memaksimalkan penerimaan pajak di negara tersebut. Konsep dari program ini sendiri adalah perubahan pola pikir dan perilaku aparat pajak serta tata nilai organisasi, sehingga dapat menjadikan Direktorat Jenderal Pajak sebagai institusi yang profesional dengan citra yang baik di mata masyarakat. Menurut Direktorat Jenderal Pajak (2007: 14) tujuan dari modernisasi sistem administrasi perpajakan yang ingin dicapai adalah meningkatkan kepercayaan masyarakat dan meningkatkan produktivitas dan integritas aparat pajak demi terwujudnya kepatuhan sukarela wajib pajak.

\section{Kepatuhan Wajib Pajak}

Menurut Rahayu, Siti (2013:138) kita dapat memberi pengertian bahwa kepatuhan perpajakan merupakan ketaatan, tunduk, dan patuh serta melaksanakan ketentuan perpajakan. Kepatuhan Wajib Pajak merupakan tujuan utama dari pemeriksaan pajak di mana dari hasil pemeriksaan pajak akan diketahui tingkat kepatuhan wajib pajak. Bagi wajib pajak yang tingkat kepatuhannya tergolong rendah (minim), maka diharapkan dengan dilakukannya pemeriksaan dapat memberikan motivasi positif agar menjadi lebih baik untuk ke depannya.

\section{Hipotesis}

Pengaruh Modernisasi Perpajakan terhadap Kepatuhan Wajib Pajak Orang Pribadi Usahawan

Kepatuhan wajib pajak dapat dipengaruhi oleh beberapa faktor yaitu kondisi sistem administrasi perpajakan suatu negara, pelayanan yang diberikan kepada wajib pajak, penegakan hukum perpajakan, pemeriksaan pajak dan tarif pajak yang berlaku. Selain itu, sistem perpajakan yang sederhana juga sangat penting karena semakin kompleks sistem perpajakan akan berpengaruh terhadap kepatuhan wajib pajak 
Modernisasi sistem administrasi perpajakan sebagai salah satu bentuk reformasi dalam memberikan pelayanan yang dilakukan oleh kantor pajak di mana akan mempengaruhi pula patuh tidaknya wajib pajak dalam melaksanakan kewajiban perpajakannya. Hal ini dikarenakan wajib pajak dalam melaporkan pajaknya dengan cara mendatangi ke kantor-kantor pajak terdekat. Jika sistem yang ada telah memberikan kemudahan terhadap wajib pajak, maka wajib pajak sendiri akan lebih patuh dalam melaksanakan kewajiban perpajakannya.

Administrasi yang baik tentunya karena instansi pajak, sumber daya aparat pajak dan prosedur perpajakannya baik. Dengan kondisi tersebut maka usaha memberikan pelayanan bagi Wajib Pajak akan lebih baik, lebih cepat dan menyenangkan Wajib Pajak. Sehingga dampaknya akan terlihat kerelaan Wajib Pajak untuk membayar pajak Rahayu, Siti (2013: 140)

Ha: Modernisasi Sistem Administrasi Perpajakan berpengaruh terhadap Kepatuhan Wajib Pajak Orang Pribadi Usahawan di ITC Cempaka Mas Jakarta

\section{METODOLOGI PENELITIAN}

\section{Populasi, Sampel, dan Teknik Pengambilan Sampel}

Objek penelitian adalah Para usahawan di ITC Cempaka Mas, Jakarta Pusat. Datadata yang diteliti adalah berupa hasil pengisian kuesioner oleh para Wajib Pajak Orang Pribadi Usahawan pada bulan Juli 2017. Untuk menentukan jumlah sampel, peneliti menggunakan saran Roscoe yang mengatakan bahwa ukuran sampel yang layak dalam penelitian adalah antara 30 sampai dengan 500 (Sugiyono 2009:129). Dan karena keterbatasan waktu, biaya, dan tenaga maka dalam penelitian ini mengambil 100 responden untuk pengambilan data kuesioner dan dengan teknik purposive.

\section{Variabel Penelitian}

Variabel penelitian pada dasarnya adalah sesuatu hal yang berbentuk apa saja yang ditetapkan oleh peneliti untuk dipelajari sehingga diperoleh informasi tentang hal tersebut, kemudian ditarik kesimpulannya. Variabel independen pada penelitian ini adalah Modernisasi Sistem Administrasi Perpajakan dimana terdapat perubahan yang dilakukan meliputi bidang-bidang berikut menurut Pandiangan (2008:7): yaitu Restrukturisasi Organisasi, Proses Bisnis Berbasis TIK , Penyempurnaan Manajemen Sumber Daya Manusia. 
Tabel 1. Indikator Variabel

\begin{tabular}{lll}
\hline Variabel & Dimensi & Indikator \\
\hline & & - Debirokrasi \\
& & - Struktur organisasi berbasis fungsi \\
& & terkait perpajakan \\
Modernisasi & - Dilakukan pemisahanantara fungsi \\
Sistem Administrasi & Restrukturisasi & pemeriksaan dengan fungsi keberatan \\
Perpajakan & Organisasi & - Adanya segmentasi Wajib Pajak \\
& & (level operasional) yang dikelola \\
& & KPP \\
& & - Lebih efisien dan "customer \\
& & oriented" \\
Modernisasi & - Berbasis teknologi komunikasi dan \\
Sistem Administrasi & Proses Bisnis & informasi \\
Perpajakan & Berbasis TIK & - Efisien dan "customer oriented" \\
& & - Sederhana dan mudah dimengerti \\
Modernisasi & & - Adanya built-in control \\
Sistem Administrasi & Penyempurnaan & - Berbasis kompetensi \\
Perpajakan & Manajemen & - Optimalisasi teknologi komunikasi \\
\hline
\end{tabular}

Variabel dependen pada penelitian ini adalah Kepatuhan Wajib Pajak Orang Pribadi dimana menurut Peraturan Menteri Keuangan RI No.74/PMK.03/2012, Wajib

Tabel 2. Dimensi dan Indikator Variabel Kepatuhan Wajib Pajak

\begin{tabular}{|c|c|c|}
\hline Variabel & Dimensi & Indikator \\
\hline & & a.Tepat waktu dalam penyampaian \\
\hline & & Pemberitahuan; (pasal 2) \\
\hline KEPATUHAN & Waiih & b. Tidak mempunyai tunggakan pajak untuk semua \\
\hline & viajiv & c.kelengkapan Surat Pemberitahuan dan lampiran \\
\hline WAJIB & Pajak & lampirannya; (pasal 7) \\
\hline & Patuh & $\begin{array}{l}\text { d. kebenaran penulisan dan penghitungan pajak; } \\
\text { (pasal 7) }\end{array}$ \\
\hline PAJAK & & $\begin{array}{l}\text { e. kebenaran pembayaran pajak yang telah dilakukan } \\
\text { oleh Wajib Pajak (pasal 7) }\end{array}$ \\
\hline
\end{tabular}




\section{Teknik Analisa Data}

\section{Uji Skala Likert}

Menurut Sugiyono (2012;132), skala likert digunakan untuk mengukur sikap, pendapat, dan persepsi seseorang atau sekelompok orang tentang fenomena sosial. Dengan skala likert, maka variabel dapat diukur menjadi indikator variabel dan dijadikan sebagai titik tolak untuk penyusunan item-item instrument yang dapat berupa penyataan atau pertanyaan. Pengukuran dilakukan dengan menghitung rata-rata jawaban berdasarkan score setiap jawaban dari resonden.

\section{Uji Reliabilitas dan Uji Validitas}

Menurut Ghozali (2016;47), Reliabilitas sebenarnya adalah alat untuk mengukur suatu kuesioner yang merupakan indikator dari variabel atau konstruk. Suatu Kuesioner dikatakan reliabel atau handal jika jawaban seseorang terhadap pernyataan adalah konsisten dan stabil dari waktu ke waktu.

Menurut Sugiyono (2016;267), validitas merupakan derajat ketepatan antara data yang sesungguhnya terjadi pada objek penelitian dengan data yang dapat dilaporkan oleh peneliti. Sehingga data yang valid adalah data yang tidak berbeda antara data yang diloporkan dengan yang sesungguhnya terjadi pada objek penelitian.

\section{Uji Statistik Deskriptif}

Uji statistik deskriptif ini menggambarkan gambaran atau deskripsi suatu data yang dilihat dari nilai rata-rata (mean), standar deviasi, varian, maksimum, minimum, sum, range.

\section{Uji Asumsi Klasik}

Pengujian yang dilakukan antara lain : (1) uji autokorelasi dengan menggunakan dengan menggunakan uji Run Test. (2) uji heteroskedastisitas dengan menggunakan uji glejser test. (3) uji normalitas dengan menggunakan non-parametik Kolmogorov-Smirnov (K-S).

\section{Analisis Regresi Linear Sederhana}

Menurut Sugiyono (2012:270), dinyatakan bahwa Regresi sederhana didasarkan pada hubungan fungsional ataupun kausal satu variabel independen dengan satu variabel dependen.

Persamaan regresi untuk menguji hipotesis penelitian ini adalah: 
$\mathrm{Y}=\alpha+\beta_{1} \mathrm{X}_{1}+\varepsilon$

Di mana:

$$
\begin{array}{ll}
\mathrm{Y} & =\text { Kepatuhan Wajib Pajak Orang Pribadi } \\
\alpha & =\text { Konstanta } \\
\beta & =\text { Koefisien Regresi } \\
\mathrm{X} & =\text { Modernisasi Sistem Perpajakan } \\
\varepsilon & =\text { Error }
\end{array}
$$

\section{Uji Hipotesis}

menunjukkan seberapa jauh pengaruh satu Pengujian yang dilakukan antara lain: (1) variabel independen secara individual Uji Koefisien Determinasi, pada intinya dalam menerangkan variasi variabel mengukur seberapa jauh kemampuan dependen (Ghozali: 2016 :97).

model dalam menerangkan variasi variabel dependen (Ghozali: 2016:96) (2) Uji

\section{HASIL \& ANALISIS}

statistik $\mathrm{F}$ pada dasarnya menunjukkan Analisis Deskriptif apakah semua variabel independen yang dimasukkan dalam model mempunyai pengaruh secara bersama-sama terhadap variabel dependen (Ghozali: 2016:96). dan Penelitian ini menggunakan kuesioner, yang di sebarkan kepada 100 responden. Sehingga diperoleh data yang menunjukan karakteristik profil para responden.

(3) Uji statistik $t$ pada dasarnya

(1) Karakteristik responden berdasarkan jenis kelamin

Tabel. 3 Karakteristik responden berdasarkan jenis kelamin

\begin{tabular}{ccc}
\hline Jenis Kelamin & Jumlah Responden & Persentase \\
\hline Laki-Laki & 53 & $53 \%$ \\
Perempuan & 47 & $47 \%$ \\
Jumlah & 100 & $100 \%$ \\
\hline
\end{tabular}

Sumber : Data Olahan SPSS 
(2) Karakteristik responden berdasarkan usia

Tabel.4 Karakteristik responden berdasarkan usia

\begin{tabular}{ccc}
\hline Usia & Jumlah Responden & Persentase \\
\hline$<25$ tahun & 13 & $13 \%$ \\
$25-35$ tahun & 54 & $54 \%$ \\
$36-45$ tahun & 22 & $22 \%$ \\
$>46$ tahun & 11 & $11 \%$ \\
Jumlah & 100 & $100 \%$ \\
\hline
\end{tabular}

Sumber : Data Olahan SPSS

(3) Karakteristik responden berdasarkan pendidikan terakhir

Tabel.5 Karakteristik responden berdasarkan pendidikan terakhir

\begin{tabular}{ccc}
\hline Pendidikan & Jumlah Responden & Persentase \\
\hline SD & - & - \\
SMP & - & - \\
SMA & 24 & $24 \%$ \\
D3/S1 & 69 & $69 \%$ \\
S2/S3 & 7 & $7 \%$ \\
Jumlah & 100 & $100 \%$ \\
\hline
\end{tabular}

Sumber : Data Olahan SPSS

(4) Karakteristik responden berdasarkan jenis usaha

Tabel.6 Karakteristik responden berdasarkan jenis usaha

\begin{tabular}{ccc}
\hline Jenis Usaha (Toko) & Jumlah Responden & Persentase (\%) \\
\hline Elektronik & 5 & $5 \%$ \\
Handphone & 37 & $37 \%$ \\
Jam Tangan & 4 & $4 \%$ \\
Kacamata & 8 & $8 \%$ \\
Kamera & 7 & $7 \%$ \\
Komputer & 21 & $21 \%$ \\
Laptop & 15 & $15 \%$ \\
Tas dan Koper & 3 & $3 \%$ \\
Total & 100 & $100 \%$ \\
\hline
\end{tabular}

Sumber: Data Olahan SPSS

(5) Karakteristik responden berdasarkan lama melakukan usaha

Tabel. 7 Karakteristik responden berdasarkan lama melakukan usaha

\begin{tabular}{ccc}
\hline Lama waktu & Keterangan & Persentase \\
\hline$<1$ tahun & 3 & $3 \%$ \\
$1-3$ tahun & 19 & $19 \%$ \\
$>3$ tahun & 78 & $78 \%$ \\
Jumlah & 100 & $100 \%$ \\
\hline
\end{tabular}

Sumber : Data Olahan SPSS 
(6) Karakteristrik responden berdasarkan lama kepemilikan NPWP

Tabel .8 Karakteristik responden berdasarkan lama kepemilikan NPWP

\begin{tabular}{ccc}
\hline Lama waktu & Keterangan & Persentase \\
\hline$<1$ tahun & 6 & $6 \%$ \\
$1-3$ tahun & 17 & $17 \%$ \\
$>3$ tahun & 77 & $77 \%$ \\
Jumlah & 100 & $100 \%$ \\
\hline
\end{tabular}

Sumber : Data Olahan SPSS

\section{Uji Sampel Validitas}

Sebelum melakukan penyebaran kusioner, dilakukan terlebih dahulu pengujian pertanyaan untuk mengetahui apakah pertanyaan dari setiap variabel dapat digunakan. Pengujian ini dilakukan pada 30 responder untuk prakuesioner dan 100 responder untuk kuesioner dengan tabel $\mathrm{r}$ terdapat pada lampiran 5. Menggunakan program SPSS versi 23.

Tabel.9 Uji Sampel Validitas Prakuesioner

\begin{tabular}{cccc}
\hline Pertanyaan & $\begin{array}{c}\text { Corrected Item-Total } \\
\text { Correlation }\end{array}$ & R Tabel & Keterangan \\
\hline X1 & 0,599 & 0,3610 & VALID \\
X2 & 0,422 & 0,3610 & VALID \\
X3 & 0,789 & 0,3610 & VALID \\
X4 & 0,594 & 0,3610 & VALID \\
X5 & 0,586 & 0,3610 & VALID \\
X6 & 0,725 & 0,3610 & VALID \\
X7 & 0,620 & 0,3610 & VALID \\
X8 & 0,507 & 0,3610 & VALID \\
X9 & 0,762 & 0,3610 & VALID \\
X10 & 0,731 & 0,3610 & VALID \\
X11 & 0,532 & 0,3610 & VALID \\
Y1 & 0,778 & 0,3610 & VALID \\
Y2 & 0,861 & 0,3610 & VALID \\
Y3 & 0,863 & 0,3610 & VALID \\
Y4 & 0,699 & 0,3610 & VALID \\
Y5 & 0,850 & 0,3610 & VALID \\
Y6 & 0,700 & 0,3610 & VALID \\
\hline
\end{tabular}


Tabel.10 Uji Sampel Validitas Kuesioner

\begin{tabular}{cccc}
\hline Pertanyaan & $\begin{array}{c}\text { Corrected Item-Total } \\
\text { Correlation }\end{array}$ & R Tabel & Keterangan \\
\hline X1 & 0,667 & 0,1946 & VALID \\
X2 & 0,645 & 0,1946 & VALID \\
X3 & 0,662 & 0,1946 & VALID \\
X4 & 0,511 & 0,1946 & VALID \\
X5 & 0,588 & 0,1946 & VALID \\
X6 & 0,540 & 0,1946 & VALID \\
X7 & 0,550 & 0,1946 & VALID \\
X8 & 0,622 & 0,1946 & VALID \\
X9 & 0,713 & 0,1946 & VALID \\
X10 & 0,572 & 0,1946 & VALID \\
X11 & 0,587 & 0,1946 & VALID \\
Y1 & 0,784 & 0,1946 & VALID \\
Y2 & 0,740 & 0,1946 & VALID \\
Y3 & 0,798 & 0,1946 & VALID \\
Y4 & 0,711 & 0,1946 & VALID \\
Y5 & 0,585 & 0,1946 & VALID \\
Y6 & 0,616 & 0,1946 & VALID \\
\hline
\end{tabular}

\section{Uji Sampel Reliabilitas}

Tabel.11 Uji Sampel Reliabilitas Prakuesioner

\begin{tabular}{cccc}
\hline Pertanyaan & $\begin{array}{c}\text { Cronbach's } \\
\text { Alpha if Item Deleted }\end{array}$ & $\begin{array}{c}\text { Cronbach } \\
\text { Alpha }\end{array}$ & KETERANGAN \\
\hline X1 & 0,830 & 0,600 & RELIABEL \\
X2 & 0,841 & 0,600 & RELIABEL \\
X3 & 0,811 & 0,600 & RELIABEL \\
X4 & 0,832 & 0,600 & RELIABEL \\
X5 & 0,828 & 0,600 & RELIABEL \\
X6 & 0,816 & 0,600 & RELIABEL \\
X7 & 0,826 & 0,600 & RELIABEL \\
X8 & 0,839 & 0,600 & RELIABEL \\
X9 & 0,811 & 0,600 & RELIABEL \\
X10 & 0,815 & 0,600 & RELIABEL \\
X11 & 0,836 & 0,600 & RELIABEL \\
Y1 & 0,862 & 0,600 & RELIABEL \\
Y2 & 0,843 & 0,600 & RELIABEL \\
Y3 & 0,843 & 0,600 & RELIABEL \\
Y4 & 0,877 & 0,600 & RELIABEL \\
Y5 & 0,846 & 0,600 & RELIABEL \\
Y6 & 0,884 & 0,600 & RELIABEL \\
\hline
\end{tabular}


Tabel.11 Uji Sampel Reliabilitas Kuesioner

\begin{tabular}{cccc}
\hline Pertanyaan & $\begin{array}{c}\text { Cronbach's } \\
\text { Alpha if Item Deleted }\end{array}$ & $\begin{array}{c}\text { Cronbach } \\
\text { Alpha }\end{array}$ & KETERANGAN \\
\hline X1 & 0,801 & 0,600 & RELIABEL \\
X2 & 0,803 & 0,600 & RELIABEL \\
X3 & 0,801 & 0,600 & RELIABEL \\
X4 & 0,817 & 0,600 & RELIABEL \\
X5 & 0,811 & 0,600 & RELIABEL \\
X6 & 0,814 & 0,600 & RELIABEL \\
X7 & 0,812 & 0,600 & RELIABEL \\
X8 & 0,806 & 0,600 & RELIABEL \\
X9 & 0,795 & 0,600 & RELIABEL \\
X10 & 0,819 & 0,600 & RELIABEL \\
X11 & 0,809 & 0,600 & RELIABEL \\
Y1 & 0,736 & 0,600 & RELIABEL \\
Y2 & 0,750 & 0,600 & RELIABEL \\
Y3 & 0,732 & 0,600 & RELIABEL \\
Y4 & 0,763 & 0,600 & RELIABEL \\
Y5 & 0,788 & 0,600 & RELIABEL \\
Y6 & 0,799 & 0,600 & RELIABEL \\
\hline
\end{tabular}

\section{Statistik Deskriptif}

Tabel.12 Statistik Dekriptif Modernisasi Sistem Administrasi Perpajakan (X)

\begin{tabular}{llrrrr}
\hline & N & \multicolumn{1}{l}{ Minimum } & Maximum & Mean & \multicolumn{1}{c}{ Std. De } \\
\hline x1 & 100 & 1 & 5 & 3,96 &, 816 \\
x2 & 100 & 3 & 5 & 4,22 &, 675 \\
x3 & 100 & 2 & 5 & 4,15 &, 744 \\
x4 & 100 & 2 & 5 & 4,11 &, 803 \\
x5 & 100 & 1 & 5 & 4,12 &, 902 \\
x6 & 100 & 2 & 5 & 4,23 &, 777 \\
x7 & 100 & 2 & 5 & 3,82 &, 702 \\
x8 & 100 & 2 & 5 & 3,85 &, 845 \\
x9 & 100 & 1 & 5 & 3,80 &, 888 \\
x10 & 100 & 1 & 5 & 3,80 & 1,073 \\
x11 & 100 & 1 & 5 & 3,89 &, 827 \\
Valid N & 100 & & & & \\
(listwise) & & & & & \\
\hline
\end{tabular}

Berdasarkan hasil di tabel, dapat disimpulkan bahwa rata-rata responden menjawab pertanyaan tentang Modernisasi pada pertanyaan $(1,7,8,9,10,11)$ menjawab
Netral dengan nilai 3, dan pertanyaan $(2,3,4,5,6)$ menjawab Setuju dengan nilai 4. 
Tabel.13 Statistik Dekriptif Kepatuhan Wajib Pajak Orang Pribadi (Y)

\begin{tabular}{lrrrrr}
\hline & N & Minimum & Maximum & Mean & Std. Dev \\
\hline y1 & 100 & 2 & 5 & 4,03 &, 846 \\
y2 & 100 & 2 & 5 & 4,11 &, 790 \\
y3 & 100 & 3 & 5 & 4,17 &, 667 \\
y4 & 100 & 2 & 5 & 4,11 &, 840 \\
y5 & 100 & 2 & 5 & 4,07 &, 671 \\
y6 & 100 & 2 & 5 & 4,00 &, 876 \\
Valid N & 100 & & & & \\
(listwise) & & & & & \\
\hline
\end{tabular}

Berdasarkan hasil di tabel, dapat disimpulkan bahwa rata-rata responden menjawab pertanyaan tentang Kepatuhan pada semua pertanyaan menjawab Setuju dengan nilai 4.

\section{Hasil Uji Asumsi Klasik}

\section{Uji Autokorelasi}

Untuk mendeteksi autokorelasi, peneliti menggunakan Run Test yang digunakan menguji apakah data residual terdapat korelasi atau tidak.

\section{Tabel.14 Uji Autokorelasi}

\begin{tabular}{cccc}
\hline Nama Pengujian & Kriteria & Hasil & Keterangan \\
\hline Uji Autokorelasi & Sig. $>0,05$ & 0,997 & $\begin{array}{c}\text { Tidak terdapat } \\
\text { Autokorelasi }\end{array}$ \\
\hline
\end{tabular}

Sumber: Data Olahan SPSS

Hasil pengujian menunjukan Melalui uji Runs- Test, hasil uji autokorelasi menunjukkan bahwa nilai sig. sebesar 0.997 atau lebih besar dari $0.05(\alpha=5 \%)$, maka dapat disimpulkan bahwa tidak tolak Ho yang menyatakan bahwa tidak terdapat autokorelasi.
Pengujian ini bertujuan untuk menguji apakah dalam model regresi terjadi ketidaksamaan variance dari residual satu pengamatan ke pengamatan yang lain. Model regresi yang baik adalah yang Homoskesdatisitas atau tidak terjadi Heteroskedastisitas. Pengujian dilakukan dengan uji Glejser

\section{Uji Heteroskedastisitas}

Tabel.15 Uji Heteroskedastisitas

\begin{tabular}{|c|c|c|c|}
\hline $\begin{array}{c}\text { Uji } \\
\text { Heteroskedastisitas }\end{array}$ & Kriteria & Hasil & Keterangan \\
\hline $\begin{array}{l}\text { Modernisasi Sistem } \\
\text { Administrasi } \\
\text { Perpajakan }\end{array}$ & Sig. $>0,05$ & 0,345 & $\begin{array}{c}\text { Tidak terjadi } \\
\text { Heteroskedastisitas }\end{array}$ \\
\hline
\end{tabular}


Hasil uji heteroskedastisitas menunjukkan nilai probabilitas berada di atas nilai sig. $0.05(\alpha=5 \%)$ yaitu sebesar 0.345. Dari hasil uji tersebut, dapat disimpulkan bahwa tidak tolak Ho yang berarti tidak terjadi heteroskedastisitas.

Uji normalitas bertujuan untuk mengetahui nilai residual berdistribusi nomal atau tidak. Pada penelitian ini menggunakan uji stastistik non-parametrik KolmogorovSmirnov. Model regresi yang baik adalah memiliki nilai residual berdistribusi normal

\section{Uji Normalitas}

\section{Tabel.16 Uji Normalitas}

\begin{tabular}{|c|c|c|c|}
\hline Nama Pengujian & Kriteria & Hasil & Keterangan \\
\hline Uji Normalitas & Sig. $>0,05$ & 0,174 & $\begin{array}{c}\text { Berdistribusi } \\
\text { Normal }\end{array}$ \\
\hline
\end{tabular}

Sumber: Data Olahan SPSS

Dari hasil uji spss menunjukkan bahwa besarnya signifikan pada 0,174 . Hal ini menunjukkan nilai sig. lebih besar dari $0.05(\alpha=5 \%)$, maka tidak tolak Ho yang berarti model regresi berdistribusi normal. Model regresi layak digunakan karena memenuhi asumsi normalitas.

\section{Analisis Regresi Linear Sederhana}

Tujuan penelitian ini adalah untuk menguji pengaruh satu variabel bebas terhadap variabel terikat

\section{Tabel.17 Analisis Regresi Linear Sederhana}

\begin{tabular}{cc}
\hline Analisis Regresi & Koefisien \\
\hline Constant & 16,637 \\
Modernisasi & 0,179 \\
\hline
\end{tabular}

Sumber: Data Olahan SPSS

Dari tabel diatas, dapat diperoleh persamaan regresi

$Y=16,637+0,179 X$

Keterangan:

$\mathrm{Y}=$ Kepatuhan Wajib Pajak Orang Pribadi

$\mathrm{X}=$ Modernisasi Sistem Administrasi Perpajakan 
Dari tabel diatas, dapat disimpulkan variabel Kepatuhan Wajib Pajak Orang Pribadi dipengaruhi oleh variabel Modernisasi Sistem Administrasi Perpajakan. Konstanta sebesar 16,637 menyatakan bahwa jika variabel independen dianggap konstan, maka ratarata Kepatuhan Wajib Pajak Orang Pribadi sebesar 16,637. Koefisien regresi Modernisasi sebesar 0.179 menyatakan bahwa setiap Modernisasi Sistem Administrasi Perpajakan akan meningkatkan Kepatuhan Wajib Pajak Orang Pribadi sebesar 0.179 .

\section{Hasil Uji Hipotesis}

Uji Koefisien Determinasi

Tabel .18 Hasil Uji Koefisien Determinasi

\begin{tabular}{cccc}
\hline Pengujian & Kriteria & Hasil & Keterangan \\
\hline Koefisien & $0 \leq \mathrm{R} 2 \leq 1$ & 0,078 & $\begin{array}{c}7,8 \% \text { variabel Kepatuhan } \\
\text { Wajib Pajak, dijelaskan di } \\
\text { variabel penelitian }\end{array}$ \\
\hline
\end{tabular}

\section{Sumber: Data Olahan SPSS}

Dari hasil uji koefisien determinasi, yaitu Modernisasi Sistem Administrasi menunjukkan bahwa besarnya adjusted $\mathrm{R}^{2}$ Perpajakan. Sementara itu, sisanya sebesar pada model summary adalah 0.078 , yang 0.922 atau $92.2 \%$ dijelaskan oleh faktorberarti 7,8\% variasi Kepatuhan Wajib faktor lain di luar dari variabel tersebut.

\section{Uji Statistik F dan $\mathbf{t}$}

Tabel.19 Hasil Uji Statistik F dant

\begin{tabular}{|c|c|c|c|}
\hline Pengujian & Kriteria & Hasil & Keterangan \\
\hline $\mathrm{Uji} F$ & Sig. $<0.05$ & 0,003 & Lolos Uji F \\
\hline Uji F & $\mathrm{F}$ hitung $>\mathrm{F}$ tabel & $9,380>3,94$ & $\begin{array}{c}\text { Terdapat pengaruh Modernisas } \\
\text { Sistem Administrasi Perpajakan } \\
\text { secara simultan terhadap Kepatuhan } \\
\text { Wajib Pajak }\end{array}$ \\
\hline
\end{tabular}

Sumber: Data Olahan SPSS

Dari Uji Statistik F ini dapat dilihat nilai sig. sebesar 0.003 atau kurang dari 0.05 ( $\alpha$ $=5 \%$ ), yang berarti model regresi ini dapat digunakan untuk memprediksi Kepatuhan Wajib Pajak. Hasilnya adalah tolak Ho atau dapat disimpulkan bahwa Modernisasi Sistem Administrasi Perpajakan berpengaruh terhadap Kepatuhan Wajib Pajak. 


\section{Uji Statistik T}

Tabel.20 Uji Statistik T

\begin{tabular}{cccc}
\hline Pengujian & Kriteria & Hasil & Keterangan \\
\hline Uji T & Sig. $<0.05$ & 0,003 & Lolos uji T \\
Uji F & T hitung $>$ T tabel & $3,063>1,98447$ & $\begin{array}{c}\text { Terdapat pengaruh Modernisasi, } \\
\text { dan Ha dapat diterima }\end{array}$ \\
\hline
\end{tabular}

Sumber: Data Olahan SPSS

Dari hasil uji $t$ menunjukkan bahwa probabilitas signifikan untuk variabel variabel Modernisasi Sistem Administrasi Perpajakan memiliki nilai sig. 0.003 atau kurang dari $0.05(\alpha=5 \%)$, yang menunjukkan adanya pengaruh terhadap Kepatuhan Wajib Pajak.

\section{Pembahasan}

Berdasarkan penelitian yang telah dilakukan, maka diperoleh hasil sebagai berikut:

Hasil pada uji $\mathrm{T}$, menunjukan adanya pengaruh positif Modernisasi Sistem Administrasi Perpajakan terhadap Kepatuhan Wajib Pajak Orang Pribadi ditunjukan pada hasil sig $0,003<0,05$ dan juga $\mathrm{T}$ hitung 3,063 lebih besar dari $\mathrm{T}$ tabel 1,98447 .

Variabel Modernisasi menghasilkan nilai sig yang lebih kecil dari 0,05 maka Modernisasi Sistem Administrasi Perpajakan terbukti berpengaruh terhadap Kepatuhan Wajib Pajak, sehingga tolak H0. Tanda positif pada koefisien menunjukkan bahwa Modernisasi Sistem
Administrasi Perpajakan berpengaruh positif signifikan.

Adapun besarnya hubungan variabel terikat (Kepatuhan Wajib Pajak) yang bisa dijelaskan oleh variabel bebas (Modernisasi Sistem Administrasi Perpajakan) sebesar 7,8\% yang dapat dilihat dari nilai Adjusted R Square. Hal ini berarti perubahan struktur organisasi, perubahan proses bisnis berbasis TIK, dan penyempurnaan manajemen SDM berpengaruh sebesar $7,8 \%$ terhadap kepatuhan wajib pajak, sedangkan sisanya $92,2 \%$ disebabkan oleh faktor-faktor lainnya.

Dapat disimpulkan bahwa Modernisasi Sistem Administrasi Perpajakan memiliki pengaruh rendah tapi memiliki pencapaian kepatuhan wajib pajak. Dan adanya faktor diluar variabel independen/bebas tersebut memiliki pengaruh yang sangat tinggi terhadap kepatuhan wajib pajak.

Hasil penelitian ini pun didukung oleh Rahayu, Siti (2013:141) bahwa kepatuhan memenuhi kewajiban perpajakan tidak hanya tergantung kepada peraturan dan 
pelayanan kepada Wajib Pajak dalam hal membayar pajak. Disamping itu juga bergantung pada kemauan Wajib Pajak juga, sampai sejauh mana Wajib Pajak tersebut akan mematuhi ketentuan peraturan perundang-undangan perpajakan.

Sehingga penelitian ini selaras dengan tujuan modernisasi perpajakan (Rahayu, Siti 2013: 117) bahwa program-program reformasi administrasi perpajakan jangka menengah Direktorat Jendral Pajak salah satunya meningkatkan Kepatuhan Perpajakan.

\section{KESIMPULAN}

\section{Kesimpulan}

Setelah dilakukan beberapa uji analisis data, maka peneliti dapat menyimpulkan bahwa Modernisasi Sistem Administrasi Perpajakan terbukti memiliki pengaruh postif terhadap Kepatuhan Wajib Pajak Orang Pribadi

Saran

Adapun saran-saran yang dapat peneliti ajukan untuk penelitian selanjutnya berdasarkan hasil analisis dan kesimpulan yang telah disampaikan, serta beberapa keterbatasan penelitian yang telah disebutkan, meliputi:

1) Penyuluhan sosialisasi perpajakan oleh DJP masih perlu ditingkatkan. Penyuluhan tersebut sebaiknya dilakukan terutama mengenai cara penggunakan dari aplikasi elektonik yang baru seperti efilling, e-billing, dan lain lain.

2) Kepatuhan Wajib Pajak dipengaruhi oleh Modernisasi Sistem Administrasi Perpajakan, sebesar 7,8\% dan sisanya dipengaruhi oleh variabel lain yang tidak dijelaskan dalam penelitian ini. Untuk itu perlu adanya penelitian lebih lanjut mengenai faktor-faktor lain yang mempengaruhi Kepatuhan Wajib Pajak

\section{DAFTAR PUSTAKA}

Cooper, Donald R. dan Schindler, Pamela S. (2017), Metode Penelitian Bisnis, Edisi Kedua Belas, Buku 1, Terjemahan oleh Rahma Wijayanti dan Gina Gania, Jakarta: Penerbit Salemba Empat.

Direktorat Jendral Pajak (2007), Modernisasi Administrasi Perpajakan, Laporan Tahunan 2007 Direktorat Jendral Pajak

Fasmi, Lasnofa dan Misra, Fauzan (2012), Modernisasi Sistem Administrasi Perpajakan dan Pengaruhnya Pada Tingkat Kepatuhan Pengusaha Kena Pajak, Jurnal Akuntansi Multiparadigma Vol 5 No 1 2014: 1169 
Ghozali, Imam (2016), Aplikasi Analisis Multivariate dengan Program IBM SPSS 23, Semarang : Badan Penerbit Universitas Diponegoro

Kamus Besar Bahasa Indonesia (KBBI). (2017, 6 8). Diambil dari Kamus Besar Bahasa Indonesia (KBBI): https://kbbi.web.id/modernisasi

Kamus Besar Bahasa Indonesia (KBBI). (2017, 6 8). Diambil dari Kamus Besar Bahasa Indonesia (KBBI): https://kbbi.web.id/administrasi

Kamus Besar Bahasa Indonesia (KBBI). (2017, 6 8). Diambil dari Kamus Besar Bahasa Indonesia (KBBI): https://kbbi.web.id/patuh

Madewing, Irmayanti (2013), Pengaruh Modernisasi Sistem Administrasi Perpajakan Terhadap Kepatuhan Wajib Pajak pada Kantor Pelayanan Pajak Pratama Makassar Utara, EJurnal Akuntansi Universitas Hasanuddin (2013)

Mardiasmo (2016), Perpajakan Edisi Terbaru 2016, Yogyakarta : C.V Andi Offset

Pandiangan, Liberti. (2008), Modernisasi \& Reformasi Pelayanan Perpajakan Berdasarkan UU Terbaru. Jakarta: PT Elex Media Komputindo

Rahayu, Siti Kurnia. (2013). Perpajakan Indonesia Konsep \& Aspek Formal. Yogyakarta: Graha Ilmu
Rahayu, Sri dan Lingga, Ita Salsalina (2009), Pengaruh Modernisasi Sistem Administrasi Perpajakan terhadap Kepatuhan Wajib Pajak (Survei atas Wajib Pajak Badan pada KPP Pratama Bandung "X"), Jurnal Akuntansi Vol.1 No.2 November 2009:119-138

Republik Indonesia. 2012. Peraturan Menteri Keuangan Nomor 74/PMK.03/2012 tentang Tata Cara Penetapan Wajib Pajak Dengan Kriteria Tertentu Dalam Rangka Pengembalian Pendahuluan Kelebihan Pembayaran Pajak. Jakarta.

Republik Indonesia. 2007. Peraturan Menteri Keuangan No. 181/PMK.03/2007 tentang Bentuk dan Isi Surat Pemberitahuan, serta Tata Cara Pengambilan, Pengisian, Penandatanganan, dan Penyampaian Surat Pemberitahuan

Resmi, Siti. (2017), Perpajakan Teori \& Kasus, Edisi 10, Buku 1, Jakarta: Penerbit Salemba Empat

Romney dan Steinbart. (2016), Sistem Informasi Akuntansi, Edisi 13, Jakarta: Penerbit Salemba Empat

Sugiyono (2012), Metode Penelitian Bisnis, Bandung : Penerbit Alfabeta

Waluyo (2017), Perpajakan Indonesia, Edisi 12, Buku 1, Jakarta: Penerbit Salemba Empat 